Nevşehir Bilim ve Teknoloji Dergisi TARGid Özel Sayı 118-129 2016

DOI: 10.17100/nevbiltek.210975

URL: http://dx.doi.org/10.17100/nevbiltek.210975

\title{
Iğdır İli Süt Sığırcılığı İşletmelerinin Sosyo Ekonomik Yapısı
}

\author{
Kasım Şahin’, Ayşe Karadağ Gürsoy \\ Iğdır Üniversitesi, Ziraat Fakültesi, Tartm Ekonomisi Bölümü, Iğdır
}

Öz

Bu çalışma, Iğdır ilinde süt sığırcılığı işletmelerinin genel özelliklerini ortaya koymak ve üretim yapısını belirlemek amacıyla yapılmıştır. Araştırmanın materyalini, Iğdır ili ve ilçelerinden basit tesadüfï örnekleme yöntemi ile seçilen toplam 86 süt sığırcılığı işletmelerine ait veriler oluşturmuştur. Çalışmada işletme başına ortalama 7.02 baş ineğin düştügü ve günlük ortalama süt veriminin $1.993,51 \mathrm{~kg} /$ baş olduğu tespit edilmiştir. Küçük, orta ve büyük ölçekli işletmelerde süt üretimi sırasıyla 4.602,02, 13.321,92 ve $35.140,00 \mathrm{~kg}$, işletme başına genel ortalama ise 10.586,41 kg olarak belirlenmiştir. Bölgede hayvan beslemede yoğun olarak çayırmera alanlarından yararlanılmasına rağmen, toplam masraflar içerisinde kesif yem masrafi yüksektir. Süt sığırcıllı̆ı işletmelerinde yem sorununun giderilmesiyle birlikte, etkin bir örgütlenme ve pazarlama alt yapısının oluşturulması zorunludur. Üreticiler elde ettikleri üretim miktarının az olmasından dolayı, ürünü satmakta sorun yaşamaktadırlar. Pazarlama sorununun aşılması için örgütlenmeleri gerekmektedir. Çiftçilerin piyasa için üretim yapacakları büyüklüğe ulaşmaları ve süt toplayan merkezler ve birlikler kurmalarıyla bu sorun çözülebilecektir. Mevcut yapısal sorunların çözümü ile süt sığırcılığı faaliyetlerinin daha rasyonel bir yapıya dönüşecektir.

Anahtar Kelimeler: Süt Sı̆̆ırcılığı, Sosyo-ekonomik Yapı, Iğdır.

\section{Socio Economic Structure of Dairy Cattle Raising Enterprises in Iğdır Province}

\begin{abstract}
This study was conducted with the aim of presenting the general characteristics of dairy cattle enterprises and their producing structure in Iğdır province. The material of the study has been the data from 86 dairy cattle enterprises selected in Iğdır province and its districts with simple random sampling method. It was found that 7.02 cows were available per enterprise and daily average milk production was 1.993,51 kg/cow. Milk production in small, medium and large scale enterprises was determined to be 4.602,02 kg, $13.321,92 \mathrm{~kg}$ and $35.140,00 \mathrm{~kg}$, respectively, and general average per enterprise was determined to be 10.586,41 kg. Although grasslands are largely benefited for grazing in the region, concentrate feed cost is high within the total costs. Along with overcoming the forage problem in dairy cattle enterprises, it is necessary to construct an effective organization and marketing infra-structure. The manufacturers are facing problems in selling their product since the output is insufficient. They should be organized so as to overcome the problem of marketing. This problem can be solved if the farmers can reach the scale at which they can produce for the market and if they can establish centers and unions collecting milk. Within this context, the enterprises have to be organized. Dairy cattle raising business will transform into a more rational structure when current structural problems are solved.
\end{abstract}

Keywords: Dairy cattle Raising, Socio-economic Structure, Iğdır.

*e-mail: kasim.sahin@igdir.edu.tr 


\section{Giriș}

Süt sığırcılığı uzun vadeli bir faaliyet kolu olup, faaliyete başlandıktan sonra, bu iş için yapılan yatırımların başka yatırımlara çevrilmesi oldukça zordur. Süt sığırcılı̆̆ına yer verilen işletmeler de kısa dönem için planlama esnekliği bulunmamaktadır. Süt fiyatları düşük olsa dahi, işletme sahipleri üretim masraflarının yüksekliğine rağmen bir süre daha üretimlerini devam ettirmek zorunda hissederler. Dolayısıyla süt üreticilerinin bu faaliyet kolunu terk etmesi kolay değildir. Çünkü süt sığırcilığı işletmelerinde ciddi yatırımlar söz konusudur [1]. Büyükbaş hayvan yetiştiriciliğinde, üretim maliyetlerinin \% 60-70'ini yem giderleri oluşturmakta ve bu durum işletmelerin karlılığını etkilemektedir [2]. Süt sığırcılığı faaliyeti, yöre şartlarına uygun hayvan varlığı yanında, işletmenin mevcut kapasitesi, üretici bilinci, sürü yönetimi, barınak şartları, aile- yabancı işgücü niteliği ve besleme tekniği gibi unsurlar rasyonel üretimi doğrudan etkilemektedir. Üretim maliyetlerinde mevcut uygulanan politikalar yanında, üretimde doğru besleme tekniklerinin kullanılması oldukça önemlidir. Üretimde sağlanan teknik başarı, işletmelerin ekonomik prensibine göre hareket etmesini kolaylaştırmakta, karlı ve verimli bir üretimin yolu açılmaktadır [3,4].

Türkiye ekonomisi içinde süt sığırcıllğı, yüksek düzeyde katma değer sağlayan tarımsal faaliyet kollarından biridir. Türkiye'de 2013 yılı verilerine göre yaklaşık 18 milyon ton civarında süt üretimi vardır. Bu miktarının \%91.39'unu inek sütü oluştururken, \% 6.04'ünü koyun sütü, \% 2.28'ini keçi sütü ve \% 0.29'unu manda sütü oluşturmaktadır. 14 milyon civarındaki toplam sığır varlığının \% 41.31'i kültür, \% 42.40’1 kültür melezi ve \% 16.29‘u da yerli ırklardan oluşmaktadır. TÜíK 2013 yılı verilerine göre Iğdır ilinde sağılan sığır sayısı 32 bin civarındadır. Bu hayvanların \% 18.70’i kültür, \% 68’i melez ve \% 13.30 ’u ise yerli ırktır. Iğdır ili süt üretimi yaklaşık 81 bin ton civarındadır [5].

Türkiye'nin en az gelişmiş bölgesi Doğu Anadolu Bölgesidir. Bu yapı diğer sektörlerde olduğu gibi tarım sektörü içinde geçerlidir. Iğdır ilinin sahip olduğu bu hayvancılık potansiyelinin geliştirilmesi ve rekabet edebilirliğini arttırmak için, sahip olunan mevcut kaynakların ve dağılımının bilinmesi önem arz etmektedir. Gıda, Tarım ve Hayvancılık Bakanlığı'nın son yıllardaki teşvikleriyle hayvancılığın geliştirilmesi için uygulamaya konulan yem bitkilerinin desteklenmesi, yem bitkileri üretimini arttırmış, hayvancılığın gelişmesine de katkı sağlamıştır [6]. Yem bitkilerindeki bu artışlar, mevcut hayvan varlığımızın kaba yem ihtiyacını karşılamak için yeterli değildir. Özellikle hayvancılığın yoğun bir şekilde yapıldığı Doğu Anadolu Bölgesi'nde yem bitkilerine yapılan desteklemeler, arttırılarak ve çeşitlendirilerek devam etmelidir [7].

Araştırmada materyal ve metot hakkında bilgi verilmiştir, araştırmaya ait bulgular başlıklar halinde tablolar yardımıyla açıklanmış ve yorumlanmıştır. Elde edilen veriler tartışma ve sonuç bölümünde yer almaktadır.

\section{Materyal ve Metot}

\subsection{Materyal}

Araştırmada görüsşme yapılacak işletme sayısının tespitinde; Iğdır ilindeki toplam işletme sayısını gösteren $\mathrm{N}$ bilinmesine karşın, bu konuda bir çalışma yapılmadığından standart sapma ve varyans değerleri bilinmediğinden, işletme sayısını belirlemek için Basit Tesadüfi Örnekleme içerisinde yer alan aşağıdaki örneklem formülü kullanılmıştır (Arıkan 2007, Yamane 2010). 


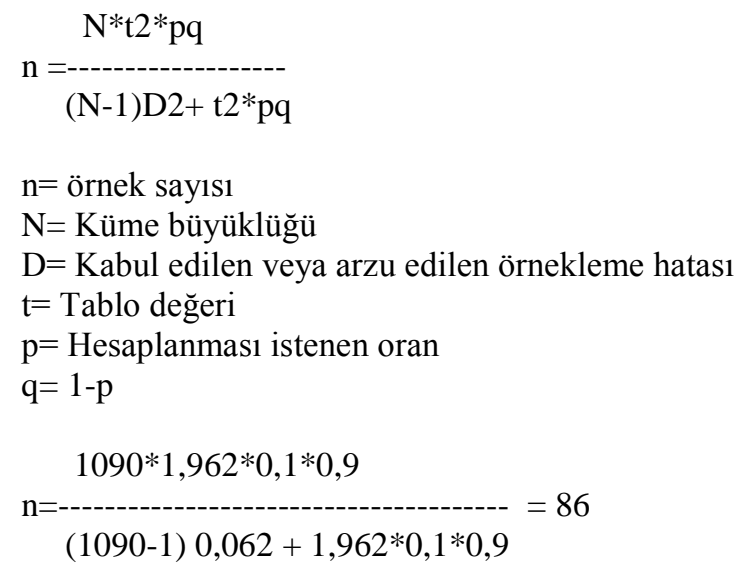

Basit tesadüfî örnekleme yöntemi ile seçilen, Iğdır ili Merkez ilçeden 27, Aralık ilçesinden 32 ve Tuzluca İlçesinden 27 süt sığırcılığg faaliyetinde bulunan 86 üreticiyle anket çalışmasından elde edilen birincil veriler oluşturmaktadır. Araştırma alanında çiftçilerle görüşülerek anket formları doldurulmuştur. Anket formları ile toplanan veriler bilgisayara girilerek değerlendirilmiştir.

\subsection{Metot}

Görüşülen çiftçilerden elde edilen veriler işletmelerin sahip oldukları hayvan varlıklarına göre gruplara ayrılarak değerlendirilmiştir. Bu amaçla görüşülen işletmelerin gruplara ayrılmasında en önemli özelliğin işletmelerde süt sığırı hayvan varlıkları olacağına karar verilmiştir. İşletmeler sahip oldukları hayvan varlıklarına göre (süt sığırcılığı hayvancılık işletmeleri) 3 gruba ayrılarak analiz edilmiştir. Bilgisayara girilen verilerin analizinde tartılı ortalamalar ve \% oranlar hesaplanarak çizelgeler haline dönüştürülmüş ve yorumlanmıştır. Araştırma kapsamında tespit edilen süt sığırcılığı işletmelerin sayısı, gruplara dağılımı ve grup ortalamaları Tablo 1'de verilmiştir.

Tablo 1. İncelenen İşletmelerde Gruplara Göre Süt Sığırı Hayvan Varlığı Dağılımı

\begin{tabular}{cccc}
\hline İşletme Grupları & Grup genişliği & İşletme Sayısı & Hayvan Varlığı (Baş) \\
I. Grup (1-5 Baş) & $1-5$ & 52 & 2.87 \\
II. Grup (6-10 Baş) & $6-10$ & 24 & 7.79 \\
III. Grup (11+ Baş) & $11+$ & 10 & 26.80 \\
Genel Toplam/Ortalama & & 86 & 7.02 \\
\hline
\end{tabular}

\section{Bulgular}

\section{İşletmelerde Nüfus, Eğitim, Mesleki Deneyim ve İşgücü Durumu}

Anket çalışması yapılan işletmelerde görüşülen kişilerin tamamı erkektir. Görüşülen işletme yöneticilerinin yaş dağılımı süt sığırcılı̆̆ı işletmelerinde ortalama 47.55 yıl, aile genişliği 5.42 kişi, işletme sahiplerinin hayvancılıkla uğraşma süresi ortalama 25.74 yıl olarak belirlenmiştir (Tablo 2).

Çorum ilinde yapılan bir araştırmada, işletmeler ortalaması olan genel ortalamaya bakıldığında nüfusun 7.65 kişi olduğu görülmüştür [8]. Kayseri ilinde süt sığırcılığı yapan işletmelerde, işletme sahiplerinin yaş ortalaması 46.8 yıl olarak tespit edilmiştir [1]. Adana ilinde yapılan çalışmada işletme sahiplerinin ortalama yaşı 48.4 yıl olarak tespit edilmiştir [2]. Aile iş gücü miktarının artması, yabancı işgücüne olan ihtiyacı da azaltması yönünden önem arz etmektedir. Erzurum'da yapılan bir çalışmada, işletme başına düşen ortalama nüfus 8.57'dir [9]. Ankara ve Aksaray'da bulunan işletmelerden ortalama birey sayısı 4.9 ve 5.5 kişi olarak hesaplanmıştır [10]. Iğdır ilinde işletme başına ortalama aile bireyi 
sayısı, önceki çalışmalara göre düşük çıkmıştır. Oysa işletmecilerin ortalama yaşı diğer çalışmalar ile paralellik göstermektedir. Kayseri ilinde süt sığırcılığı yapan işletmelerde, işletme sahiplerinin hayvancılıkla ilgili mesleki deneyim süresi 17.8 olarak hesaplanmıştır [1]. Adana ilinde yapılan çalışmada süt sığırcıllı̆̆ üretim faaliyetindeki ortalama deneyim süresini 20.5 yıl olarak hesaplanmıştır [2].

Tablo 2. İşletmeci İle İlgili Bilgiler

\begin{tabular}{cccc}
\hline & Yaş Ortalaması & Kişi Sayısı & Mesleki Deneyim \\
İşletme Grupları & 47.06 & 5.25 & 25.19 \\
I. Grup & 50.08 & 5.88 & 26.67 \\
II. Grup & 44.00 & 5.20 & 26.40 \\
III. Grup & 47.55 & 5.42 & 25.74 \\
G. Toplam &
\end{tabular}

Türkiye'de son yıllarda süt sığırı işletme sahiplerinin yapısında bir değişim yaşanmakta, sığırcılıkla ilgilenen insanların kendini yenilemesi, eğitim seviyesi ileri kişiler ve iş adamlarının da süt sığırcılığına yatırım yapmasıdır [11]. Eğitim düzeyi ile işletmelerde elde edilen verim arasında yakın bir ilişki bulunması ve tarımsal üretimin bilinçli yapıldığı yörelerde eğitim oranının genellikle yüksek olduğu bilinmektedir [12]. Bu amaçla görüşülen işletme sahiplerinin eğitim durumu da incelenmiştir.

Süt sığırcılığı işletmelerinde ilkokul mezunlarının oranının \% 70.93 olduğu görülmektedir. Bunu \% 13.95 ile lise, \% 8.14 ile okur- yazar ve \% 6.98 ile de ortaokul mezunları takip etmektedir. Yüksekokul veya üniversite mezunu olan işletme sahiplerine rastlanılmamıştır (Tablo 3).

Adana ilinde yapılan çalışmada, süt sığırcılığı üretim faaliyetindeki işletme sahiplerinin \% 57.6's1 ilkokul, \% 15.2'si ortaokul, \% 10.6'sı lise, \% 3'ü üniversite ve \% 13.6's1 okur-yazar olduğu belirlenmiştir [2]. Erzurum ilinde büyükbaş hayvancılık yapan işletmelerde nüfusun \% 67.07'sini ilkokul mezunu, \% 10.66'sını okuma yazma bilmeyenler, \% 9.33'ünü ise ortaokul mezunları oluşturmaktadır. Yine ortalama nüfusun \% 6.80'inin okuryazar, \% 5.87'sinin lise mezunu ve \% 0.27'sinin de yüksekokul mezunu olduğu tespit edilmiştir [9]. Uşak ilinde yapılan bir araştırmada, işletme sahiplerinin \% 58'i ilkokul mezunu, \% 16's1 ortaokul mezunu, \% 20'si lise mezunu, \% 6's1 üniversite mezunudur [11]. Yapılan bir araştırmada, ilkokul mezunu olanların oranı Ankara'da \% 63.0, Aksaray'da \% 76.0'dır. Ortaokul, lise ve yüksekokul mezunu işletme sahiplerinin oranı Ankara'da sırasıyla \% 9.6, \% 12.9 ve \% 14.5; Aksaray'da ise yine aynı sırayla \% 8.5, \% 12.7 ve \% 1.4 olarak hesaplanmıştır [10]. Karabük ilinde yapılan bir araştırmada, tahsil durumu açısından işletme sahiplerinin; \% 61 inin ilköğretim, \% 26.8 inin Lise, \% 7.3’ü lisans mezunudur. İşletmecilerin \% 4.9’u ise diğer, öğretim durumunu belirtmemiş olduklarından bilinmemektedir [13].

\begin{tabular}{|c|c|c|c|c|c|c|c|c|c|c|}
\hline \multirow{2}{*}{ İssletme Grupları } & \multicolumn{2}{|c|}{ Okur-Yazar } & \multicolumn{2}{|c|}{ İlkokul } & \multicolumn{2}{|c|}{ Ortaokul } & \multicolumn{2}{|c|}{ Lise } & \multicolumn{2}{|c|}{ Toplam } \\
\hline & Kişi & $\%$ & Kişi & $\%$ & Kişi & $\%$ & Kişi & $\%$ & Kişi & $\%$ \\
\hline I. Grup & 4 & 7.69 & 36 & 69.23 & 5 & 9.62 & 7 & 13.46 & 52 & 100 \\
\hline II. Grup & 2 & 8.33 & 19 & 79.17 & 0 & 0.00 & 3 & 12.50 & 24 & 100 \\
\hline III. Grup & 1 & 10.00 & 6 & 60.00 & 1 & 10.00 & 2 & 20.00 & 10 & 100 \\
\hline G. Toplam & 7 & 8.14 & 61 & 70.93 & 6 & 6.98 & 12 & 13.95 & 86 & 100 \\
\hline
\end{tabular}

Hayvancılık, özellikle süt sığırcılı̆̆ı yoğun emek isteyen bir tarımsal faaliyet koludur. Hayvancılıkta işgücünün kaynağını aile fertleri ve yabancı işgücü oluşturur [14]. Araştırma alanında istihdam edilen yabancı işgücü içinde, bayan (kadın) işgücüne rastlanılmamıştır. Süt sığırcılığ1 
işletmelerinde, yabancı işgücü istihdam eden işletmelerin oranı \% 11.62 olup, işletme grupları itibariyle bu oranda önemli farklılıklar gözlenmiştir. Yabancı işgücü istihdam eden işletmelerde, ortalama istihdam edilen işgücü 1 kişidir. Erzurum'da yapılan bir araştırmada, yabancı işgücü çalıştıran işletmelerin oranı \% 5.74 olarak tespit edilmiştir [9]. Ankara'daki işletmelerin 22'si (\% 35.5) ve Aksaray'daki işletmelerin de 27'sinin (\% 19.0) işçi veya çoban çalıştırdıkları anlaşılmıştır. Bu işletmelerde çalışan toplam işçi veya çoban sayısı Ankara için 39 (1.8 kişi/işletme), Aksaray için 61 (2.3 kişi/işletme) kişi olarak hesaplanmıştır [10]. Araştırma alanındaki belirlenen, yabancı işgücü istihdam eden işletmelerin oranı ve ortalama istihdam edilen işgücü miktarı, yukarıda belirtilen araştırma verilerinden düşük bulunmuştur.

\section{İşletmelerde Arazi Varlı̆̆ı ve Arazinin Kullanım Durumu}

İşletmelerde ortalama arazi varlığı 41.97 dekar olup, bunun \% 94.31’i (39.58 dekar) mülk, \% 3.33’ü (1.4 dekar) kiralık arazi ve \% 2.36'sı (0.99 dekar) ortakçılık arazisinden oluşmaktadır (Tablo 4).

Çorum ilinde yapılan bir araştırmada, işletmeler ortalamasına bakıldığında mülk arazisinin 17.18 dekardır [8]. Amasya ilinde yapılan bir araştırmada, incelenen besicilik işletmeleri ortalama 52 dekar işletme arazisine sahiptirler [16]. Araştırma alanında bulunan ortalama arazi değeri yukarıdaki çalışmalardan yüksek bulunmuştur. Ancak bu miktar, Türkiye ortalamasından (59.93 dekar) düşüktür [1].

Tablo 4. İşletmelerin Arazi Varlı̆̆ı ve Mülkiyet Durumu

\begin{tabular}{ccccccccc}
\hline İşletme Grupları & \multicolumn{2}{c}{ Mülk Arazi } & \multicolumn{2}{c}{ Kira Arazi } & \multicolumn{2}{c}{ Ortak Arazi } & \multicolumn{2}{c}{ Toplam } \\
Alan (da) & \% & Alan (da) & \% & Alan (da) & \% & Alan (da) & \% \\
I. Grup & 26.83 & 95.24 & 0.67 & 2.38 & 0.67 & 2.38 & 28.17 & 100.00 \\
II. Grup & 58.46 & 95.57 & 1.25 & 2.04 & 1.46 & 2.39 & 61.17 & 100.00 \\
III. Grup & 60.60 & 89.64 & 5.50 & 8.14 & 1.50 & 2.22 & 67.60 & 100.00 \\
G. Toplam & 39.58 & 94.31 & 1.40 & 3.33 & 0.99 & 2.36 & 41.97 & 100.00 \\
\hline
\end{tabular}

Süt sığırcılığı işletmelerinde, ortalama işlenen alan 14.55 dekar olup, bunun 5.0 dekarı buğday, 4.14 dekarı yonca ve 3.12 dekarı da arpa ekilidir. İşletme grupları arasında ürünlerin ekim alanları açısından önemli farklılık görülmektedir. I. ve III. grup işletmelerde Korunga ekimi yapılan işletmeye rastlanılmamıştır (Tablo 5).

Tekirdağ ilinde yapılan bir araştırmada, işletme sahiplerinin \% 57'si yonca, fiğ gibi yem bitkisi yetiştirmekte iken \% 43'ü yem bitkisi üretimi yapmamaktadır. Hayvancılıkla uğraşan işletmelerin büyük çoğunluğu bitkisel üretim yapmakta, bu üretiminde büyük bir kısmı diğer bitkilerin yanında yem bitkisi de yetiştirmektedir [15]. Ankara ve Aksaray illerinde kaba yem olarak ekimi yapılan yem bitkileri korunga, yonca ve silajlık mısır'dır. Korunga ekimi Ankara'da 3 işletme, Aksaray'da 6 işletmede gerçekleştirilmektedir. Yonca eken işletmelerin oranı Ankara'da \% 48.4, Aksaray'da \% 69.7, silajlık mısır ekimi yapan işletmelerin oranı da aynı sırayla \% 33.9 ve \% 44.4'tür. Arpa ve buğday eken işletmelerin oranı her iki ilde de oldukça yüksektir [10].

Tablo 5. İşletmelerin Yem Bitkisi Ekim Alanları (da)

\begin{tabular}{ccccccccc}
\hline İșletme Grupları & Buğday & Arpa & Tane Mısır & Silaj Mısır & Yonca & Korunga & Diğer & Toplam \\
I. Grup & 4.37 & 0.87 & 0.19 & 0.23 & 3.52 & 0.00 & 0.00 & 9.18 \\
II. Grup & 5.96 & 3.54 & 1.63 & 0.42 & 0.83 & 2.17 & 0.25 & 14.80 \\
III. Grup & 6.00 & 13.80 & 0.00 & 6.80 & 15.30 & 0.00 & 0.00 & 41.90 \\
G. Toplam & 5.00 & 3.12 & 0.57 & 1.05 & 4.14 & 0.60 & 0.07 & 14.55 \\
\hline
\end{tabular}


İşletme başına ortalama yem bitkileri üretimi Tablo 6'da verilmiştir. Tabloya göre işletme başına ortalama 4.13 ton silajlı mısır üretilirken, 10.16 ton yonca ve 0.86 ton korunga üretilmektedir. Bu üretim miktarları işletme grupları arasında farklılık göstermektedir.

Yapılan bir araştırmada, silajlık mısır, kuru yonca ve arpa için dekara verim Ankara ilinde 3.530 kg, 387 kg, 250 kg; Aksaray ilinde de 3.477 kg, 702 kg ve 248 kg olarak hesaplanmıştır. İki ilin dekara yonca verimi değerleri arasındaki fark dikkat çekicidir [10].

Tablo 6. İşletmelerin Yem Bitkisi Üretimi (ton)

\begin{tabular}{cccc}
\hline İşletme Grupları & Silajlık Mısır & Yonca & Korunga \\
I. Grup & 0.38 & 8.54 & 0.00 \\
II. Grup & 1.46 & 1.25 & 3.08 \\
III. Grup & 30.00 & 40.00 & 0.00 \\
G. Toplam & 4.13 & 10.16 & 0.86 \\
\hline
\end{tabular}

\section{İşletmelerde Bina Varlığı ve Kullanım Durumu}

İncelenen işletmelerin bina varlığı ortaya konmuş, işletmelerin sahip oldukları binaların (ev, ahır, samanlık, yem deposu, ambar) kullanım alanları ve yapım yılları incelenmiştir. İşletmelerin sahip oldukları ortalama ev genişliği $123.62 \mathrm{~m}^{2}$ dir. İncelenen işletmelerde ahır alanı $98.48 \mathrm{~m}^{2}$, samanlık 29.05 $\mathrm{m}^{2}$, ambar $5 \mathrm{~m}^{2}$ ve yem deposu $0.17 \mathrm{~m}^{2} \operatorname{dir}$ (Tablo 7).

Çorum ilinde yapılan bir araştırmada, işletme büyüklük grupları itibariyle işletmelerin sahip oldukları binaların kapasitesi incelendiğinde toplam kapasitenin \% 35 konut, \% 28.94'ü ahır, \% 24.64'ü ağıl, \% 10.32'si samanlık, \% 0.86'sını da ambar oluşturmaktadır [8].

Tablo 7. İşletmelerin Bina Alanları $\left(\mathrm{m}^{2}\right)$

\begin{tabular}{ccccccc}
\hline Isșletme Grupları & Ev & Ahır & Samanlık & Yem Deposu & Ambar & Toplam \\
I. Grup & 123.25 & 85.15 & 21.42 & 0.00 & 2.98 & 232.80 \\
II. Grup & 121.33 & 112.29 & 31.21 & 0.00 & 9.79 & 274.62 \\
III. Grup & 131.00 & 134.60 & 63.50 & 1.50 & 4.00 & 334.60 \\
G. Toplam & 123.62 & 98.48 & 29.05 & 0.17 & 5.00 & 256.32 \\
\hline
\end{tabular}

İşletmelerin ev, ahır ve samanlık yapım yılları dikkate alınarak, binaların yaşı hesaplanmıştır. Tablo 8 incelendiğinde, evlerin ortalama yaşı 17.42 yıl, ahırların 14.07 yıl ve samanlığın yapım yılı 6.64 yıl olarak tespit edilmiştir. İşletme grupları incelendiğinde ev, ahır ve samanlı̆̆ın ortalama yapım y1llarının dalgalanma gösterdiği görülecektir.

Tablo 8. İşletmelerdeki Binaların Yaşı (yıl)

\begin{tabular}{cccc}
\hline İşletme Grupları & Ev & Ahır & Samanlık \\
I. Grup & 17.83 & 15.15 & 6.48 \\
II. Grup & 15.96 & 12.83 & 7.42 \\
III. Grup & 18.80 & 11.40 & 5.60 \\
G. Toplam & 17.42 & 14.07 & 6.64 \\
\hline
\end{tabular}

\section{İşletmelerde Alet Ekipman Varlığı}

Süt sığırcıllğı hayvan işletmelerinde kullanılan alet ekipman varlığı Tablo 9'da verilmiştir. İşletme başına ortalama traktör varlığ 0.22 adet, römork 0.24 adet, pulluk 0.20 adet, kültivatör 0.06 adet, balya makinası 0.03 adet, batöz 0.13 adet, gübre dağıtma makinası 0.01 adet, su motoru 0.07 adet, tırmık 0.20 adet ve ot biçme makinası 0.17 adettir (Tablo 9). 
Şahin K., Karadağ Gürsoy A.

Tablo 9. İşletmelerde Alet Ekipman Varlığı (ortalama adet)

\begin{tabular}{cccccc}
\hline İșletme Grupları & Traktör & Römork & Pulluk & Kültivatör & 0.04 \\
I. Grup & 0.12 & 0.10 & 0.08 & 0.13 & 0.00 \\
II. Grup & 0.38 & 0.46 & 0.38 & 0.00 & 0.04 \\
III. Grup & 0.40 & 0.50 & 0.40 & 0.06 & 0.20 \\
G. Toplam & 0.22 & 0.24 & 0.20 & 0.03 \\
\hline
\end{tabular}

Tablo 9. devamı

\begin{tabular}{cccccc}
\hline İşletme Grupları & Batöz & Gübre Dağıtma Makinası & Su Motoru & Tırmık & Ot Biçme Makinası \\
I. Grup & 0.04 & 0.00 & 0.04 & 0.08 & 0.08 \\
II. Grup & 0.21 & 0.04 & 0.13 & 0.38 \\
III. Grup & 0.40 & 0.00 & 0.10 & 0.40 & 0.30 \\
G. Toplam & 0.13 & 0.01 & 0.07 & 0.20 & 0.17 \\
\hline
\end{tabular}

\section{İşletmelerde Büyükbaș Hayvan Varlığı}

İncelenen işletmelerde, gruplar büyüdükçe doğal olarak, işletme gruplarındaki ortalama hayvan varlığ 1 da artış göstermektedir. I. grup işletmelerde 4.01 baş, II. grup işletmelerde 13.54 baş ve III. grup işletmelerde 34.90 baş hayvan varlığı bulunmaktadır. İncelenen işletmelerde ortalama hayvan varlı̆̆ı 10.25 baş olarak tespit edilmiştir (Tablo 10).

Tablo 10 da görüleceği üzere işletmelerde ağıllıklı olarak süt sığırı bulunmaktadır. İşletme başına ortalama süt sığırı sayısı 7.02 baş, düve 1.09 baş, dana 1.05 baş ve besi sığırı 0.87 baştır.

Tablo 10. İşletme Gruplarına Göre Büyükbaş Hayvan Varlığı (baş)

\begin{tabular}{ccccccccc}
\hline İşletme Grupları & Besi Sığırı & Süt Sı̆̆ırı & Buzağı & Dana & Düve & Tosun & Boğa & Toplam \\
I. Grup & 0.06 & 2.87 & 0.04 & 0.65 & 0.37 & 0.00 & 0.02 & 4.01 \\
II. Grup & 2.58 & 7.79 & 0.00 & 1.50 & 1.25 & 0.21 & 0.21 \\
III. Grup & 1.00 & 26.80 & 0.00 & 2.00 & 4.50 & 0.10 & 0.50 & 34.54 \\
G. Toplam & 0.87 & 7.02 & 0.02 & 1.05 & 1.09 & 0.07 & 0.13 & 10.25 \\
\hline
\end{tabular}

\section{İşletmelerde Hayvansal Üretim Durumu}

İncelenen işletmelerde ortalama süt miktarı $10.586,41 \mathrm{~kg}$ dır. I., II. ve III. grup işletmelerde sırasıyla süt üretim miktarları 4.602,02 kg, 13.321,92 kg ve 35.140,00 kg dır. İşletme başına günlük ortalama süt verimi ise $1.993,51 \mathrm{~kg} / \mathrm{baş} \mathrm{dır.} \mathrm{İşletme} \mathrm{grupları} \mathrm{büyüdükçe} \mathrm{süt} \mathrm{üretimi} \mathrm{ve} \mathrm{verim} \mathrm{artmaktadır}$ (Tablo 11).

Tablo 11. İşletmelerin Toplam Süt Üretim (kg) ve Verim Miktarı (kg/baş)

\begin{tabular}{ccc}
\hline İşletme Grupları & Süt Üretimi & Verim \\
I. Grup & $4.602,02$ & $1.797,76$ \\
II. Grup & $13.321,92$ & $2.265,56$ \\
III. Grup & $35.140,00$ & $2.358,52$ \\
G. Toplam & $10.586,41$ & $1.993,51$ \\
\hline
\end{tabular}

İncelenen hayvancılık işletmelerinde başta süt olmak üzere, peynir, yoğurt ve tereyağı üretimi yapılmakta, işletme içinde tüketilerek veya pazarlanarak değerlendirilmektedir. Bu kapsamda satılan veya işletmede tüketilen miktarlar Tablo 12'de verilmiştir. İşletme başına ortalama 5.068,90 kg süt, $768.35 \mathrm{~kg}$ peynir, $139.07 \mathrm{~kg}$ yoğurt ve $6.98 \mathrm{~kg}$ tereyağı satılmış veya tüketilmiştir. Hayvansal üretim miktarları işletme grupları arasında farklılık göstermektedir.

Tablo 12. İşletmelerin Hayvansal Üretim Miktarı (kg)

\begin{tabular}{ccccc}
\hline İşletme Grupları & Süt & Peynir & Yoğurt & Tereyağı \\
I. Grup & $2.465,87$ & 290.38 & 103.46 & 5.10 \\
II. Grup & $6.237,50$ & 978.25 & 236.67 & 8.96 \\
III. Grup & $15.800,00$ & $2.750,00$ & 90.00 & 12.00 \\
G. Toplam & $5.068,90$ & 768.35 & 139.07 & 6.98 \\
\hline
\end{tabular}




\section{İşletmelerde Para ve Kredi Durumu}

İncelenen işletmelerde mevcut para miktarı, işletmelerin alacakları ile işletmede bulunan nakit para kısmından oluşmaktadır. Para sermayesi, işletme sermayesi içinde en hareketli sermaye grubunu teşkil etmektedir.

İncelenen süt sığırı hayvancıllk işletmelerinde kasa mevcudu olarak nakit paraya rastlanılmamıştır. İşletme başına ortalama alacak miktarı 110.47 TL iken, borç miktarı 12.457,56 TL olarak belirlenmiştir. İşletme grupları büyüdükçe borç miktarı da artış göstermektedir (Tablo 13).

Tablo 13. İşletmelerin Kasa Durumu (TL)

\begin{tabular}{ccc}
\hline İşletme Grupları & Alacaklar & Borçlar \\
I. Grup & 48.08 & $7.727,88$ \\
II. Grup & 291.67 & $11.916,67$ \\
III. Grup & 0.00 & $38.350,00$ \\
G. Toplam & 110.47 & $12.457,56$ \\
\hline
\end{tabular}

İncelenen süt sığırı hayvancılık işletmelerinde Türkiye Cumhuriyeti Ziraat Bankasından (TCZB) kullanılan ortalama kredi miktarı 32.622,50 TL olup, vade süresi 33.60 ay olarak tespit edilmiştir. Diğer kredi kuruluşlarından kullanılan ortalama kredi tutarı 43.333,33 TL olup vade süresi 36.00 aydır. İncelenen işletmelerin yaklaşık \%37.21'i T.C. Ziraat Bankasından kredi kullanmaktadır. Diğer kredi kuruluşlarından kredi kullandığını beyan eden işletmelerin oranı oldukça düşüktür (\%3.49).

\section{İşletmelerin Tarımla İlgili Kuruluşlara Üyelik Durumu}

Tarımla ilgili kuruluşlarda, üyelerin birbirini tanıması aralarında belli zaman aralıklarında dayanışma toplantılarının olması birliğin devamlılı̆ı ve daha geniş bir yelpazeye yayılması ildeki etkinliğini artırması bakımından önem taşımaktadır. Birliklerde amaç bizzat yetiştiricilerin kendi sorunlarına çözüm bulmasıdır. Bu tür toplantıların bu duruma hizmet etmesi açısından önemli olduğu düşünülmektedir.

Kooperatifler kurularak sütün ortak bir soğutma tankında toplanması ve toplu olarak pazarlanmas1, sütün kalitesini arttıracak ve beraberinde de daha yüksek fiyatla istenildiği şekilde pazarlanmasına olanak sağlayacaktır. Yine bu yolla yem hammaddelerinin toplu alımı gerçekleştirilip, ortak alınacak yem kırma makinesi ile üreticiler yemi kendileri üreterek üretim maliyetlerini azaltabilirler. Küçük işletmelerin birleşerek orta- büyük işletme kurmaları her birinin katkısı oranında hisseye sahip olması önerilebilir. Bu şekilde büyük modern işletmeler kurulabilir. Bu da girdi maliyetlerinin azalması, daha kaliteli süt eldesi dolayısıyla karlılı̆̆ın artması sonucunu beraberinde getirecektir [15].

Görüşülen hayvancılık işletmelerinde süt sığırcıllğı hayvancılık işletmelerinin (29 adet) \% 33.72'sı tarımla ilgili bir kuruluşa üyedir. Bu işletmelerden \% 55.17'si damızlık birliğine, \% 44.83'ü başta sulama birliğine olmak üzere, üretici birliği, arıcılar birliği, koyun birliği ve hayvancılık birliğine üye olduklarını belirtmişlerdir.

\section{İncelenen İşletmelerde Hayvancılıkla İlgili Sorunlar ve Çözüm Önerileri}

Iğdır ilinde yapılan çalışma kapsamında, hayvansal üretim yapan üreticilerin sorunlarını ve çözüm önerilerini tespit etmek amacıyla açık uçlu sorular sorulmuş sorunların ve çözüm önerilerinin yüzde dağılımları verilmiştir. 
Görüşülen işletmelerde hayvansal üretime yönelik sorunlar arasında ilk sıray1 \% 75.58 ile yem fiyatlarının yüksekliği alırken, bunu \% 68.60 ile yaylaların kurak ve yetersiz olması, \% 33.72 ile hayvanları ucuz olması, \% 30.23 ile yem bitkisi yetiştirememe (su yetersizliğinden) ve \% 15.12 ile bakım masraflarının yüksek olması sorunu izlemektedir (Şekil 1).

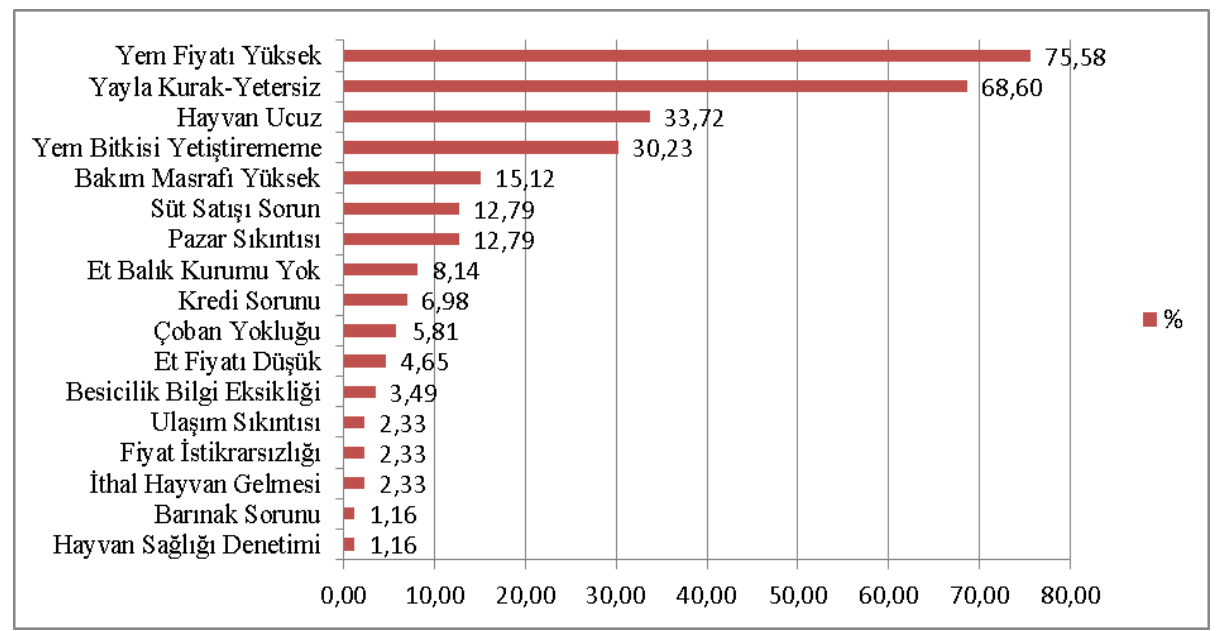

Şekil 1. İşletmecilerin Hayvancılığa İlişkin Sorunları

Görüşülen işletmelerde sunulan çözüm önerileri arasında ilk sırayı \% 53.49 ile mera alanları artırılsın alırken, bunu \% 51.16 ile yeme destek verilmesi, \% 32.56 ile tarıma destek sağlanması, \% 31.40 ile ithal hayvan gelmesi ve \% 26.74 ile kredi desteği sağlanması izlemektedir (Şekil 2).

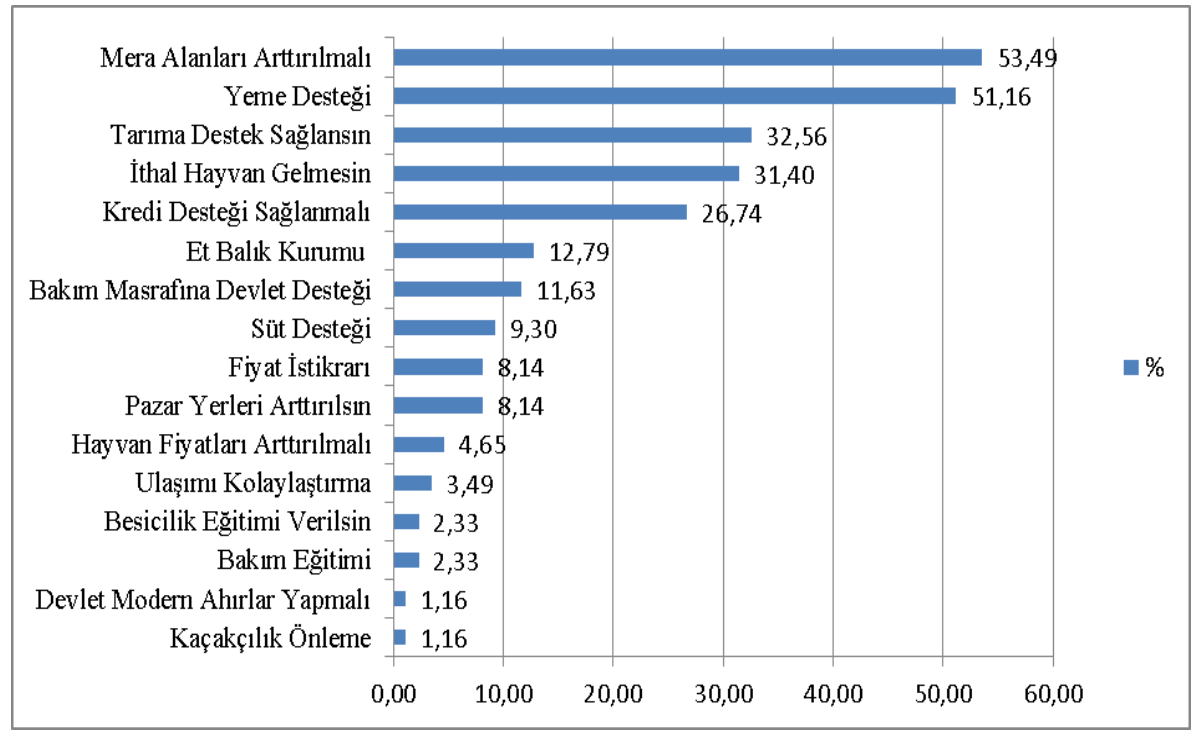

Şekil 2. İşletmecilerin Hayvancılığa İlişkin Çözüm Önerileri

\section{Tartışma ve Sonuç}

Iğdır ilinde canlı hayvan alımları hayvan panayırları, belediye hayvan pazarları ve işletmelerde (köy içi) gerçekleşmektedir. Hayvan satış şekilleri ise canlı ağırlık ve dış görünüşlerine bakılarak yapılmaktadır. Araştırmanın yapıldığı Iğdır ili ekolojik hayvancılık açısından önemli bir potansiyele sahiptir. Hayvancılık daha çok ekstansif olarak yapılmakta bu nedenle birçok hayvancılık dalında çok düşük girdi kullanılmaktadır. Koyun ve keçi yetiştiriciliği daha çok meraya dayalı olarak yürütülmekte ve 
çoğu işletmelerde hayvanların yem gereksinimleri mera ve yayla gibi doğal otlatma alanlarından karşılanmaktadır.

Hayvan üretim yapan işletmelerde, verimi artırmanın temel kurallarından birisi verimi yüksek ırklarla çalışmaktır. Verim artışını sağlamanın temelinde verimi yüksek kültür ırklarla çalışmak ve bakım ve besleme şartlarını iyileştirmeden geçmektedir. Devletin son yıllarda uygulamakta olduğu suni tohumlama desteği sayesinde kültür ırkı ve melezi hayvanların oranının artmasında önemli katkı sağlayacaktır. Ayrıca bakım ve besleme şartlarının iyileştirilmesi, verimliliği artırmak açısından en az ırkların iyileştirilmesi kadar büyük önem kazanmaktadır.

Üreticiler elde etikleri ürünün az olmasından satmakta sorun yaşamaktadır. Pazarlama sorununun aşılması için örgütlenmeleri gerekmektedir.

Çiftçilerin piyasa için üretim yapacakları büyüklüğe ulaşmaları ve süt toplayan merkezler ve birlikler kurmalarıyla bu sorun çözülebilecektir. $\mathrm{Bu}$ bağlamda da işletmelerin örgütlenmesi gerekmektedir.

Iğdır ilinin hayvansal üretim potansiyelinin geliştirilmesi için sahip olduğu birçok avantajlı durum vardır. Bunlar; hayvancıllğa yönelik hammaddenin kolay temin edilebilir olması, organik tarım için müsait alanların olması, transit geçiş bölgesinde olması ve beraberinde ihracata uygun bir coğrafi konumda olması, Nahçıvan ve İran ile sınır ticareti kapsamında günübirlik ticaret olanağına sahip olması, iklim ve topoğrafik yapısının elverişli olması ve bölgesel teşviklerin varlığıdır.

İlde tarım ve hayvancılığın cazip yatırım aracı olması ve hayvancılık işletmelerinin aile işletmesi şeklinde olması nedeniyle ticari gelecek kaygısı duymamaktadırlar. Bu işletmelerde işgücü maliyetlerinin ve risk unsurunun düşük olması, hayvansal üretim açısından farklı üretim biçimlerine uygun ekoloji büyük firsatlar ve potansiyel oluşturmaktadır.

Hayvancılığın yaşlı nüfus tarafından yapılması, hayvancılıkla uğraşan nüfusun eğitim düzeyinin düşüklüğü ve girişimcilik kültürünün zayıflığı işletmelerin gelişip büyümesi karşısındaki en önemli olumsuz koşullardır. Ayrıca hayvancılık işletmelerinde, ortak iş yapma durumunun olmaması ve örgütlenme sorunu da başka bir olumsuzluk olarak karşımıza çıkmaktadır.

Iğdır ilinde hayvancılık işletmelerinde yaşanan hayvan sağlığı ile ilgili sorunlar ve yeterli veterinerlik hizmetinin olmaması, kısa sürede çözülmesi gereken sorunların başında gelmektedir.

İşletmelerde karşılaşılan yüksek üretim maliyetleri ve yem fiyatlarının yüksekliği, yem üretiminin işletmelerde üretilmesiyle bir dereceye kadar çözülebilir. Aynı zamanda başta yem bitkilerinin desteklenmesi olmak üzere işletmelerin devlet desteğine ihtiyacı olduğu da açıktır.

Iğdır ilinde ekolojik tarımın yaygınlaştırılması ile doğanın ve eko sistemin korunmasına, küçük çifţilerin gelir düzeyinin artırılmasına, agro-turizm ve kırsal kalkınmaya, köyden kente göçün önlenmesine, başta çocuklar olmak üzere insanlar için daha sağlıklı ürün üretilmesine neden olmaktadır. Ekolojik tarımın desteklenmesi ile birlikte; eğitim, denetim ve üretimden pazarlamaya kadar çok iyi bir organizasyonun oluşturulması gerekmektedir.

Devlet tarafından uygulanan destekleme politikaların popülist yaklaşımlı ve kısa vadeli oluşu nedeniyle yapılan desteklerin devamlılığı aranmamaktadır. Yapılan destekler olduğu gibi kalmaktadır. $\mathrm{Bu}$ desteklemelerin devamlılığı önem arz etmektedir. Destekleme politikalarının tarımsal yapıya uygun 
olarak belirlenmesi gerekmektedir. Bilgi ve teknolojinin yeterince ilgili yerlere ulaştırılamamaktadır. Bilgi ve teknoloji olmadan gerekli ve yeterli gelişmenin olmasını beklemek mümkün değildir.

Ülkemizin bütün tarım altyapısında olduğu gibi, hayvancılık yatırımlarında da orta ve uzun vadeli tarım politika planlamaları yapılmamıştır. Planlama olmadan başarılı çalışmaların yapılmasını beklemek mümkün değildir. Planlama derken yalnızca yönetim planlaması değil aynı zamanda üretim planlaması da yapmak gerekmektedir. Üretim planlaması hangi bölgede hangi tip hayvancıllı̆ın destekleneceğini de baştan belli edeceğinden yöneticilerin özel önem vermesi gereken konuların başında gelmektedir.

Tarımsal destekler verildikten sonra bunların amaca uygun şekilde kullanılıp kullanılmadığının denetimi yeterince yapılmamaktadır. Bunun sonucu olarak ta hayvancılı̆̆ın gelişmesi için alınan destekler amacının dışında kullanılmaktadır. Verilen teşviklerin başarılı bir şekilde yerine getirilebilmesi için modern girdi ve teknolojilerin yeterince kullanılmasının sağlanması gereklidir.

\section{Kaynaklar}

[1] Şahin, K., Yılmaz, İ. H., "Van İlinde Yem Bitkileri Tarımı, Mera Kullanımı ve Sosyo Ekonomik Yapı Üzerine Bir Araştırma” Ankara Üniversitesi Ziraat Fakültesi Tarım Bilimleri Dergisi, 14 (4) S: 414-419, 2008

[2] Şahin, K., Gül, A., Koç, B., Dağıstan, E., “Adana İlinde Entansif Süt Sığırcıllğı Üretim Ekonomisi” Yüzz̈̈ncü Yll Üniversitesi Ziraat Fakültesi Tartm Bilimleri Dergisi, 11(2): 19-28, 2001

[3] Demir, P., Aksu Elmalı, D., Işık, S., Tazegül, R., Ayvazoğlu, C., "Kars İli Süt Sığırcılık İşletmelerinde Yem Kullanımı Ve Hayvan Besleme Alışkanlıklarının Ekonomik Önemi" Atatürk Üniversitesi Veteriner Bilimleri Dergisi, 8(3), sayfa:229-236, 2013

[4] Tatar, A. M., "Ankara Ve Aksaray Damızlık Sığır Yetiştiricileri İl Birliklerine Üye Süt Sığırcıllğı İşletmelerinin Yapısı ve Sorunları” Ankara Üniversitesi Fen Bilimleri Enstitüsü, Doktora Tezi, 119s, Ankara, 2007

[5] Yavuz F., Akbulut Ö., Keskin A., "Türkiye Sığırcılık Sektöründe Islah Ve Destekleme Politikalarının Etkinliği Üzerine Bir Araştırma” Turkish Journal of Veterinary Animal Science, Say1: 27, Sayfa: 645-650, 2003

[6] Topçu, Y., "Erzurum İli Sığır Besiciliği İşletmelerinde Girdi Kullanımı Ve Üretim Maliyeti Üzerine Bir Araştırma” Atatürk Üniversitesi Ziraat Fakültesi Dergisi, Sayı:35, sayfa:65-73, 2004

[7] Toker, M. T., Karabıyık, İ., “Ovacık Hayvancıllı̆ı'nın Stratejik Planı Analiz Çalışması” 2012, Karabük

[8] Fidan, H., "Çorum İlinde Sığır Yetiştiriciliği Yapan Tarım İşletmelerinin Ekonomik Analizi ve Hayvansal Ürünlerin Maliyet Unsurlarının Araştırılması” Ankara Üniversitesi Fen Bilimleri Enstitüsü, Yüksek Lisans Tezi, 376s, Ankara, 1992

[9] Külekçi, M., "Erzurum İli Hayvancılık İşletmelerinin AB Muhasebe Sistemine (FADN) Göre Sınıflandırılması Ve Değerlendirilmesi; Karayazı, Tekman Ve Çat İlçeleri Örneğì" Atatürk Üniversitesi Fen Bilimleri Enstitüsü, Doktora Tezi, 131s, Erzurum, 2006 
[10] Temel, S., Şahin, K., "Iğdır İlinde Yem Bitkilerinin Mevcut Durumu, Sorunları Ve Çözüm Önerileri” Yüzüncü Yıl Üniversitesi Ziraat Fakültesi Tarım Bilimleri Dergisi, 21 (1): 64-72, 2011

[11] Köse, K., "Uşak İli Damızlık Sığır Yetiştiriciler Birliğine Kayıtlı İşletmelerin Genel Yapısı" Trakya Üniversitesi Fen Bilimleri Enstitüsü, Yüksek Lisans Tezi, Tekirdağ, 2006

[12] Şahin, K., Yılmaz, İ. H., "The Effects of Subsidizing Forage Production on Animal Production in Van” Turkey Journal of Animal and Veterinary Advances, 8(3): 492-495. ISSN: 1680-5593, 2009

[13] TÜİK, 2013. http://tuikapp.tuik.gov.tr/hayvancilikapp/hayvancilik.zul/ [Ulaşım:05.01.2015]

[14] Şahin, K., “Adana İli Seyhan ve Yüreğir İlçelerinde Süt Sığırcılığı Yapılan İşletmelerde Kaynak Kullanımı ve Verimlilik” Çukurova Üniversitesi Fen Bilimleri Enstitüsü, Yüksek Lisans Tezi, 69s, Adana, 1993

[15] Soyak, A., “Tekirdağ İli Süt Sığırcılığı İşletmelerinin Yapısal Özellikleri ve Bu İşletmelerin Siyah Alaca Süt Sığırı Popülasyonunun Çeşitli Morfolojik Özellikleri Üzerine Bir Araştırma" Trakya Üniversitesi Fen Bilimleri Enstitüsü, Yüksek Lisans Tezi, Tekirdağ, 2006

[16] Hazneci, K., “Amasya İli Suluova İlçesinde Sığır Besiciliği Yapan İşletmelerin Etkinlik Analizi” Ondokuz Mayıs Üniversitesi Fen Bilimleri Enstitüsü, Yüksek Lisans Tezi, Samsun, 2007 